\title{
Strongyloides stercoralis and other Enteroparasites in Children at Uberlândia City, State of Minas Gerais, Brazil
}

\author{
Eleuza Rodrigues Machado, Julia Maria Costa-Cruz ${ }^{+}$
}

\begin{abstract}
Laboratório de Parasitologia, Departamento de Patologia, Universidade Federal de Uberlândia, Av. Pará 1720, 38400-902 Uberlândia, MG, Brasil
\end{abstract}

To evaluate the rate of infection by Strongyloides stercoralis and other enteroparasites a survey was conducted in the city of Uberlândia, State of Minas Gerais, Brazil. A total of 900 stool samples from 300 children aging from four months to seven years, randomly selected in ten nursery schools from September 1994 to December 1995, were examined, both by the Baermann-Moraes and Lutz methods. Thirty nine children (13\%) were found to be infected by S. stercoralis, $64.1 \%$ were boys and $35.9 \%$ were girls. Taking all the enteroparasites as a whole the results of the survey pointed out that $265(88.4 \%)$ of the 300 children were infected by the following: Giardia lamblia, 78.3\%; Ascaris lumbricoides, $15.3 \%$; S. stercoralis, 13\%; Hymenolepis nana, 6.7\%; hookworms, 6\%; Enterobius vermicularis, 4\%; Hymenolepis diminuta, $4 \%$ and Trichuris trichiura, $0.7 \%$. From 265 infected children $64.5 \%$ were mono-infected, $27.2 \%$ were infected by two parasites and $8.3 \%$ had a poly-specific parasite burden. It was concluded that strongyloidiasis is hyperendemic in this area.

Key words: Strongyloides stercoralis - intestinal parasites - children - Brazil

Strongyloidiasis has heterogenic worldwide distribution, with three world regions, according to the predominance of the infection by Strongyloides stercoralis (Bavay, 1876): sporadic $(<1 \%)$, endemic $(1-5 \%)$ and hyperendemic $(>5 \%)$ (Stuerchler 1981 apud Pires \& Dreyer 1993).

The occurrence of $S$. stercoralis in children aged from 0-14 years in some Brazilian states is summarized in Table I.

This study aimed at surveying the prevalence of $S$. stercoralis and other enteroparasites in nursing school children aging from four months to seven years, in Uberlândia, State of Minas Gerais, Brazil, from September 1994 to December 1995.

\section{MATERIALS AND METHODS}

In 1994 Uberlândia had 49 nursery schools, from these ten were taken at random. The size of the sample was calculated according to the formula: $\mathrm{n}=\mathrm{Z}^{2} \times \mathrm{P} \times \mathrm{Q} / \mathrm{d}^{2}$ (Rodrigues 1986) considering (Z) of $95 \%$; (d) of $5 \%$; (P) of $10 \%$, obtained in a pilot study in three nursery schools, and a non-observed value (Q) of $90 \%$; with the size of the sample (n) evaluated at 138 persons. This sample was amplified and 300 children were selected at random, 30 at each of the pre-determined school; these children were later identified according to sex and

\footnotetext{
Supported by CAPES.

${ }^{+}$Corresponding author. Fax: +55-34-218.2333

Received 10 July 1997

Accepted 17 November 1997
}

age following the agreement of their parents or tutors for their participation.

Three fecal samples from each child were collected in plastic vials without preservatives with intervals of four to six days. The samples were stored in boxes with ice and analyzed at the Laboratory of Parasitology of the Universidade Federal de Uberlândia by the methods of Baermann and Moraes (BM) (Baermann 1917, Moraes 1948) and Lutz (Lutz 1919). For more adequate reading of the slides the larvae were fixed using $0.2 \mathrm{ml}$ of a $10 \%$ solution of formalin applied to the residue of the first method. Five slides were prepared for the $\mathrm{BM}$ analysis and six for the Lutz analysis for each of the 900 samples. The total number of slides examination was thus 9900 .

All the families of the children received the results of the laboratory diagnosis. The positive cases were referred to the Pediatric Polyclinic, where they received specific treatment.

The data were processed using the analysis of variance (Anova) and the Students' $t$ according to Malleta (1992).

\section{RESULTS}

S. stercoralis infection - From the 300 children studied $39(13 \%)$ were infected with larvae of $S$. stercoralis in one of the three periods sampled. Of these cases, 28 cases were detected only by BM method $(71.8 \%)$, nine of them only by the Lutz' method $(23.1 \%)$ and two by both methods $(5.1 \%)$. These differences were statistically significant by Anova, GL 2 and 6. Of these 39 cases nine (23\%) 
were diagnosed only in the first sample; one (2.6\%) in the first and third; one $(2.6 \%)$ in all three samples; 14 cases $(35.9 \%)$ in the second sample and $14(35.9 \%)$ only in the third sample. These variations were not statistically significant by Anova GL 2 and 6. Regarding sex 25 (64.1\%) cases of $S$. stercoralis were detected in boys and 14 $(35.9 \%)$ in girls. Children in all ages were infected, except in those from zero up to one year. Table II has the number of children studied and test results by age category. There was no statistically significant difference in rates of infection by sex or age. Positive cases of $S$. stercoralis varied from 3.3\% to $23.3 \%$ in the ten nursery schools.

Other enteroparasites - Of the 300 children studied $149(49.7 \%)$ were boys and 151 , girls $(50.3 \%)$. Of these 265 (88.4\%) were infected: 132 $(49.8 \%)$ were boys and $133(50.2 \%)$ were girls. The distribution of parasites, (excluding the positive children from the other sample) is represented in Table III. There were $171(64.5 \%)$ children mono-infected; 72 (27.2\%) bi-infected and 22 (8.3\%) poly-infected. From the bi and poly-infected children there were 32 associated infections of $S$. stercoralis: Giardia lamblia, Stiles, 1915, in 17 cases (53.1\%); Ascaris lumbricoides, Linnaeus, 1758, in four (12.5\%); hookworms either Ancylostoma duodenale (Dubini, 1843) or Necator americanus, Stiles, 1903, in one (3.1\%); Hymenolepis nana (Siebold, 1852) in one (3.1\%); together with G. lamblia and A. lumbricoides in five (15.6\%); G. lamblia and hookworms in two (6.2\%); $G$. lamblia and $H$. nana in one (3.1\%) and $G$. lamblia and Enterobius vermicularis (Linnaeus, $1771)$ in one (3.1\%).

\section{TABLE II}

Distribution of the 39 cases of Strongyloides stercoralis by age category of the children studied in Uberlândia between September 1994 and December 1995

\begin{tabular}{lcccc}
\hline $\begin{array}{l}\text { Age } \\
\text { category } \\
\text { (year) }\end{array}$ & $\begin{array}{c}\text { No. of } \\
\text { children } \\
\text { examined } \\
(\mathrm{n}=300)\end{array}$ & $\begin{array}{c}\text { No. of } \\
\text { positive } \\
\text { cases } \\
(\mathrm{n}=39)\end{array}$ & $\begin{array}{c}\text { \% by } \\
\text { positive } \\
\text { cases }\end{array}$ & $\begin{array}{c}\% \text { by } \\
\text { age } \\
\text { category }\end{array}$ \\
\hline $0 \neg 1$ & 8 & 0 & 0 & 0 \\
$1 \neg 2$ & 55 & 6 & 15.4 & 10.9 \\
$2 \neg 3$ & 61 & 8 & 20.5 & 13.1 \\
$3 \neg 4$ & 48 & 6 & 15.4 & 12.5 \\
$4 \neg 5$ & 55 & 7 & 17.9 & 12.7 \\
$5 \neg 6$ & 42 & 8 & 20.5 & 19.0 \\
$6 \neg 7$ & 31 & 4 & 10.3 & 12.9 \\
\hline
\end{tabular}

TABLE III

Frequency of enteroparasites among children aged from four months to seven years from ten nursery schools in Uberlândia, from September 1994 to December 1995

\begin{tabular}{lcc}
\hline Parasites & $\begin{array}{c}\text { No. of positive } \\
\text { children }\end{array}$ & $\%$ \\
\hline Giardia lamblia & 235 & 78.3 \\
Ascaris lumbricoides & 46 & 15.3 \\
Strongyloides stercoralis & 39 & 13 \\
Hymenolepis nana & 20 & 6.7 \\
Hookworms & 18 & 6 \\
Enterobius vermicularis & 12 & 4 \\
Hymenolepis diminuta & 12 & 4 \\
Trichuris trichiura & 2 & 0.7 \\
\hline
\end{tabular}

TABLE I

Occurrence of strongyloidiasis in children in different states of Brazil

\begin{tabular}{|c|c|c|c|c|c|}
\hline State & $\begin{array}{r}\text { No. of } \\
\text { hildren }\end{array}$ & Age category & $\begin{array}{c}\text { No. of } \\
\text { positive }(\%)\end{array}$ & $\begin{array}{l}\text { Parasitological } \\
\text { methods }\end{array}$ & Authors (year) \\
\hline Minas Gerais & 1021 & $0-14$ years old & $82(8)$ & Direct & Alonso (1967) \\
\hline Amazonas & 240 & $0-12$ years old & $4(1.7)$ & Faust & Ferraroni et al. (1979) \\
\hline Pernambuco & 4312 & $0-14$ years old & $102(2.4)$ & Lutz & Alves et al. (1982) \\
\hline Maranhão & 2634 & $0-14$ years old & $758 \quad(28.8)$ & $\begin{array}{l}\text { Direct, Rugai, } \\
\text { Faust, Lutz }\end{array}$ & Cutrim-Jr et al. (1985) \\
\hline Rio Grande do Norte & 4441 & $0-14$ years old & 159 (2.9) & $\begin{array}{l}\text { Lutz, Graham, } \\
\text { BM }\end{array}$ & Cavalcanti-Jr et al. (1987) \\
\hline Mato Grosso & 149 & 3-72 months & $5(3.3)$ & Lutz & Latorraca et al. (1988) \\
\hline Pernambuco & 459 & $0-13$ years old & $44(9.6)$ & Ritchie, Brumpt & Okazaki et al. (1988) \\
\hline Goiás & 1296 & $3-23$ months & $79(6.1)$ & Lutz, Faust & Santos et al. (1990) \\
\hline Rio Grande do Norte & 134 & $1-14$ years old & $32(23.9)$ & Lutz, BM & Albuquerque et al. (1990) \\
\hline Distrito Federal & 298 & $1-12$ years old & $9(3)$ & Ritchie & Almeida (1992) \\
\hline Minas Gerais & 94 & $0-12$ years old & $2(2.1)$ & Lutz & Gennari-Cardoso et al. (1996) \\
\hline
\end{tabular}

BM: Baermann and Moraes. 


\section{DISCUSSION}

To the present time the records of children infected with S. stercoralis in the city of Uberlândia varied from zero (Berbert-Ferreira \& Costa-Cruz 1995) and 2.1\% (Gennari-Cardoso et al. 1996). Both of these studies were conducted using only one sample per case and using only the Lutz' method.

Using the procedure of three samples per child and two methods for diagnosis the rate of infection was found to be considerably increased, $13 \%$. It is recommend that for effective diagnosis three samples are necessary: $71.8 \%$ of the cases in the present research were identified only in second and third samples. Additionally, the BM method was able to identify the infection in $30(76.9 \%)$ of children studied.

No children of the 0-1 age category were found to be infected with $S$. stercoralis compatible with other research previously published: Marzochi and Carvalheiro (1978), Almeida and Costa-Cruz (1988), Berbert-Ferreira and Costa-Cruz (1995), Guimarães and Sogayar (1995). In the other age categories the rate of positive cases varied from $10.3 \%$ to $20.5 \%$ for S. stercoralis involving, $10.9 \%$ to $19 \%$ of children, indicating that this parasite is hyperendemic in the city.

In terms of other detected enteroparasites the rate of infection $(88.4 \%)$ was classified as severe considering the damage that these etiologic entities may inflict on their hosts. This rate of infection is the highest found so far in this city, even when other age categories have been included (Costa-Cruz et al. 1991, Sá \& Costa-Cruz 1991, Berbert-Ferreira \& Costa-Cruz 1995, Costa-Cruz et al. 1996, Gennari-Cardoso et al. 1996). G. lamblia was the only pathogenic protozoon detected (235 cases). Seven species of helminthes were identified, of which A. lumbricoides presented the highest rate: $15.3 \%$. The occurrence of $35.5 \%$ of children infected by more than one parasite demonstrated that enteroparasites represent a serious problem to the public health of Uberlândia.

\section{ACKNOWLEDGMENTS}

To Maria Cristina Mouta Rink for statistical analysis, to Prof. Dr Uriel Franco Rocha and Dr David G Francis for suggestions.

\section{REFERENCES}

Albuquerque LMM, Cavalcanti-Junior CB, Ribeiro MD 1990. Eosinofilia sangüínea em crianças com helmintíases intestinais. Rev Anál Clin 22: 26-30.

Almeida IS 1992. Prevalência de Giardia lamblia em população infantil e condições ambientais no bairro Nossa Senhora de Fátima, Planaltina, D.F. Bras Méd 29: 5-10.
Almeida LP, Costa-Cruz JM 1988. Incidência de enteroparasitas em habitantes do município de Araguari, Minas Gerais. Rev Cen Ci Bioméd Univ Fed Uberlândia 4: 9-17.

Alonso MT 1967. Incidência de protozooses e helmintoses intestinais em crianças no Triângulo Mineiro. Hospital 72: 315-320.

Alves JGB, Ferreira OS, Rocha JA 1982. Parasitoses intestinais em crianças atendidas no Ambulatório do Instituto Materno Infantil de Pernambuco (IMIP). $J$ Pediat Rio de Janeiro 52: 15-16.

Baermann G 1917. Eine Einfache Methode zur Auffindung von Ankylostomum (Nematoden) Larven in Erdproben. Mededeel mit h. Geneesk. Lab Weltvreden Feestbundel, Batavia, p. 41-47.

Berbert-Ferreira M, Costa-Cruz JM 1995. Parasitas intestinais em lactentes de 4 a 12 meses, usuários das creches da Universidade Federal de Uberlândia, Minas Gerais. J Pediatr Rio de Janeiro 71: 219-222.

Cavalcanti-Junior GB, Ribeiro MD, Brito TNS, Araujo MCPE, Medeiros MCC 1987. Frequiência de parasitoses intestinais numa amostra da população infantil do Rio Grande do Norte. Rev Bras Anál Clin 19: 75-76.

Costa-Cruz JM, Ambrósio MR, Marques DE, GennariCardoso ML, Couto JDV 1991. Inquérito coproparasitológico em escolares de Uberlândia, MG. Rev Soc Bras Med Trop 24 (Suppl. II): 141.

Costa-Cruz JM, Ferreira MS, Rossin IR 1996. Intestinal parasites in AIDS and +HIV patients in Uberlândia, Minas Gerais, Brazil. Mem Inst Oswaldo Cruz 91: 685-686.

Cutrim-Junior RJC, Fonseca PHM, Carneiro SFM 1985. Prevalência de entero-helmintos em pré-escolares e escolares do bairro da Vila Palmeira, São Luís - MA. Arq Bras Med 59: 467-468.

Ferraroni MJR, Montoril-Filho M, Ferraroni JJ 1979. Parasitas intestinais numa população humana da cidade de Nova Olinda do Norte, Amazonas. Acta Amazônica 9: 657-659.

Gennari-Cardoso ML, Costa-Cruz JM, Castro E, Lima LMFS, Prudente DV 1996. Cryptosporidium sp. in children suffering from acute diarrhea at Uberlândia city, State of Minas Gerais, Brazil. Mem Inst Oswaldo Cruz 91: 551-552.

Guimarães S, Sogayar MJL 1995. Occurrence of Giardia lamblia in children of municipal day-care centers from Botucatu, São Paulo State, Brazil. Rev Inst Med Trop São Paulo 37: 501-506.

Latorraca MQ, Meirelles SMP, Marchini JS 1988. Indicadores das condições nutricionais na região polonoroeste. V: desnutrição proteico-energética e parasitoses intestinais em um grupo de crianças de 3 a 72 meses de idade da cidade de Mirassol d'oeste, Mato Grosso, Brasil. Rev Inst Med Trop São Paulo 30: 192-196.

Lutz AV 1919. Schistosoma mansoni e a schistosomose, segundo observações feitas no Brasil. Mem Inst Oswaldo Cruz 11: 121-125.

Maletta CHM 1992. Bioestatística em Saúde Pública. 2nd. ed., Coopmed, Belo Horizonte, MG, 301 pp. Marzochi MC, Carvalheiro JR 1978. Estudos dos fatores 
envolvidos na disseminação dos enteroparasitas. Rev Inst Med Trop São Paulo 20: 31-35.

Moraes RG 1948. Contribuição para o estudo do Strongyloides stercoralis e da estrongiloidíase no Brasil. Rev Saú Públ 1: 507-624.

Okazaki M, Miranda P, Neto J, Diegues V, Alves J, Machado C, Tanabe M, Kobayashi S, Kaneto N, Nagakura K, Kobayashi M, Motta S, Taneto S, Takeuchi T 1988. Parasitological and serological studies on amoebiasis and other intestinal parasitic infections in Recife and its suburban area, Northeast Brazil. Rev Inst Med Trop São Paulo 30: 313-321.

Pires ML, Dreyer G 1993. Revendo a importância do
Strongyloides stercoralis. Rev Hosp Clin Fac Med São Paulo 48: 175-182.

Rodrigues PC 1986. Bioestatística, Ed. Universitária, Niterói, RJ, 227 pp.

Sá MAR, Costa-Cruz JM 1991. Incidência de enteroparasitas nos centros de saúde do município de Uberlândia-MG, no ano de 1988. Rev Soc Bras Med Trop 24 (Suppl. II): 141.

Santos MAQ, Paçô JM, Isac E, Alves EL, Vieira MA 1990. Prevalência estimada de parasitas intestinais em escolares de creches e estabelecimentos de ensino em Goiânia - Goiás. Rev Patol Trop Goiânia 19: 35 45 . 